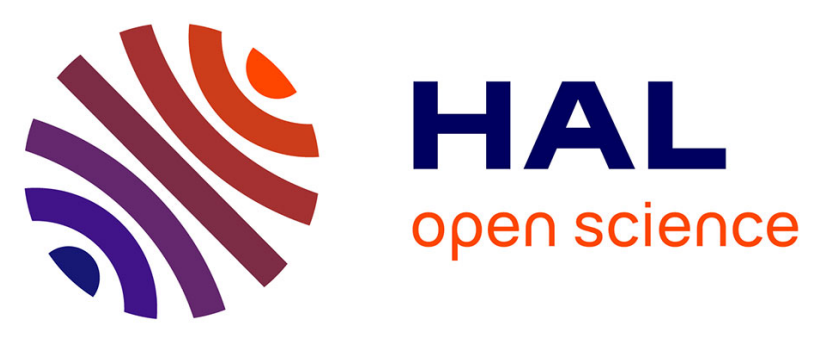

\title{
Creation of the Junior Practices in Reflection Committee of the French Speaking Ergonomics Society: Historical Genesis and Theoretical Foundation of the Exchange on Practice
}

\author{
Alexis Chambel, Danie Jon, Camille Bachellerie, Camille Toulisse
}

\section{To cite this version:}

Alexis Chambel, Danie Jon, Camille Bachellerie, Camille Toulisse. Creation of the Junior Practices in Reflection Committee of the French Speaking Ergonomics Society: Historical Genesis and Theoretical Foundation of the Exchange on Practice. International Ergonomics Association 21st Triennial Congress, Jun 2021, Vancouver, Canada. pp.454-461, 10.1007/978-3-030-74602-5_64 . hal-03277363

\section{HAL Id: hal-03277363 \\ https://hal.science/hal-03277363}

Submitted on 3 Jul 2021

HAL is a multi-disciplinary open access archive for the deposit and dissemination of scientific research documents, whether they are published or not. The documents may come from teaching and research institutions in France or abroad, or from public or private research centers.
L'archive ouverte pluridisciplinaire HAL, est destinée au dépôt et à la diffusion de documents scientifiques de niveau recherche, publiés ou non, émanant des établissements d'enseignement et de recherche français ou étrangers, des laboratoires publics ou privés. 


\title{
Creation of the Junior Practices in Reflection committee of the French Speaking Ergonomics Society: historical genesis and theorical founda-tion of the exchange on practice
}

\author{
CHAMBEL Alexis[1-2] JON Danie[1-3] BACHELLERIE Camille[4] TOULISSE Ca-mille[5]
}

1 : Ergonomist, Ph.D student, AECTT-EVS UMR 5600, Université Lumière Lyon 2, France

2 : Parcours Doctoral National en Santé Travail, France

3 : Kardham, France

4 : Ergonomist, Ph.D student, Conservatoire national des arts et métiers, CREAPT, France

5 : Ergonomist, Head of the internal Occupational Health Service of Département de l'Ain, France

\begin{abstract}
This article is part of a wider symposium which aims to present what has been developed by the Junior Practices in Reflection Committee of the French Speaking Ergonomics Society (SELF) in terms of exchange on practice. It is the first communication of a symposium and focuses more specifically on the genesis of the Committee. We will first develop the needs that led to its emergence, then the conceptual anchoring, particularly the use of the storytelling that is mobilized. Finally, the various actions that have been implemented since its creation will be developed.
\end{abstract}

Keywords: Reflective practice, ergonomics of the activity, discussion engineering, junior practice

\section{$\underline{\text { Introduction }}$}

This article is the first in a series of four constituting a symposium. It presents the Junior Practices in Reflection Committee (JPR) of the French Speaking Ergonomics Society (SELF) and the reflective spaces, the "days for exchange on the practice", that has been set up since its creation. This symposium first communication looks more specifically at the genesis of the Commission.

Before going into more detail on the genesis, it seems important to come back to the object of these exchanges: the practice. Commonly used term, it carries by essence a certain polysemy. First, it can be mobilised from the perspective of opposition to knowledge, in reference to the traditional concept of logos and praxis. It is then often reduced to the simple application of knowledge. The ex-pression can also be used to characterise the repetition of the action from the perspective of mastery of a skill. While these two approaches give us some clues to what the practice is, it is important to better delineate its contours.

The practice of a profession can be defined as "a situated professional activity, oriented by purposes, goals and standards of an occupational group. It results in the application of knowledge, processes and skills in action of a person in a professional situation." [2]. Contrary to the usual representation of simple application, it implies a reflection of its own, which is performed before, during and after the action [17]. Moreover, this definition has two important characteristics:

- First, it offers the possibility to think about the articulation between the individual and the collective, which refers to the concept of "community of practice" [13;23] and can be synthetically defined as a group of individuals united around three structuring dimensions: 
mutual commitment, sense of joint enterprise and shared repertoire of resources. We will return more particularly to this notion in the course of the text.

- Then, it makes practice part of its relationship to action. It is a setting in motion of knowledge and methods in articulation with the complexity of situations, with the contingencies of reality that the ergonomist has to deal with. It can thus be differentiated by its situated character from other similar concepts such as technique, which refers rather to a know-how, to a precise method that may be disconnected from the situation.

Therefore, talking about one's practice refers to a personal way of doing things, marked by both singularity and repetition, in accordance with a form of collective action, and shared within a community structured around common norms and goals.

It is fundamentally this need for a space for discussion on practice that led to the first members of the Committee in 2014 : Sarah Couillaud, Damien Cromer, Laurène Elwert, Fabien Francou et Karen Hubert and the SELF then chaired by François Hubault, to set up a specific Committee on this subject. However, the object of our Committee is more restricted, it concerns the Junior Practices, understood as up to 6 years of practice of the profession of ergonomist. This positioning is based on a twofold observation : the existence of problems specific to novice ergonomists and the lack of space to instruct them. We will develop these different points in a first part, before getting to the heart of our methodology in a second part: the mobilization of the reflexive professional storytelling, finally concluding on the declinations and the contribution of this engineering to the various forms of discussion we are developing.

\section{Genesis of the Committee}

Although the Committee is not intended to represent novice practitioners, it is nevertheless possible for us, based on our own experience and the literature, to put forward hypotheses. These relate first to the specific difficulties encountered by novice practitioners who participated in the creation of the Committee. They also relate to what prevents their instruction in existing spaces within the community.

\subsection{Reflection on the difficulties encountered by novice practitioners}

The profession of ergonomist has been the subject of numerous studies in the field of ergonomics of the activity, particularly from a formative perspective [3;10;21]. It can be characterized from three perspectives [12]. The first views ergonomics as a diagnostic activity, the second as a design activity and the third as a collaborative problem-solving activity, thus placing it in the service domain. These three perspectives provide food for thought, both in terms of the relationship with experience and the difficulties encountered by the ergonomist [4].

The first two points of view lead us to consider the repertoire of situations available to the ergonomist. In the first case, it is a question of carrying out a process of categorization of the situation encountered regarding the known categories. In the second, the situation reference frame feeds "an iterative, nonlinear resolution process based on the experience of past solutions" [4]. One of the difficulties for ergonomists is "the limit of their reference system" [21]. Indeed, the practice of ergonomics is characterized by an extreme diversity of classes of situations that may be encountered by the practitioner. In their encounter with reality, practitioners draw on the library of situations they have experienced in order to enter into dialogue with the singular case they find themself confronted with. 
The existence in their experience of similar, or at least approximate, cases then enables them to provide a more satisfactory response, both from the point of view of their own values and objectives, but also regarding the relevance of their action.

Although this difficulty is not exclusive to young practitioners, it is nevertheless more marked during the beginning of the professional career, when this library of situations can only marginally be enriched by the practice of the ergonomist themself. This leads some authors $[3 ; 10 ; 12]$ to underline the importance of developing this library of situations during the training of ergonomists. The sharing of experience then becomes one of the methods envisaged.

The works on training, more specifically in the field of professional didactics, also shed some light on the difficulties that young practitioners may encounter. By focusing on conceptualization for action, these works have made it possible to identify "pragmatic concepts" [16], concepts which can be defined as "schematic and operative representations, elaborated by and for action, which are the product of a historical and collective process, and which are transmitted essentially through experience and companionship" [16]. We will simply retain here the anchoring of these concepts with action and practice. Rather, it is their relationship with other concepts and fields of knowledge [22] that is important for our purposes.

The first link that deserves to be developed is the relationship to the theoretical concepts acquired during the formation. Based on work on the operation of nuclear power plants, Pastre [15] shows that the knowledge acquired during training cannot be used directly but is subject to "pragmatization". This process can be defined in a synthetic way as the creation of an operational model that makes it possible to move from an understanding of the operation to the actual operation. In the context of ergonomics, a parallel can be drawn with the intervention. It is one thing to know the theoretical sequence, its different stages, and its composition. It is another to combine this knowledge with the complexity of reality to carry out an intervention.

The second link concerns the relationship to daily concept and is specific to service activities. In this type of activity, a process of professionalization of daily concepts takes place [14]. For our action in everyday life and throughout life we mobilize a whole set of concepts organizing our activity which differs from the pragmatic concept because it is not associated with a professional activity. For example [14], "Doing the housework" for a home helper will require adjustments because it is not the same to do the housework for one or another person's home. This will require some respect for the place where the person lives and adaptations to the person's quality criteria. In the same case, another daily concept of "helping the other" may also require adjustments, sometimes helping means letting go to develop autonomy. As these concepts are already mobilized in action in everyday life, it is not pragmatization that is at stake "since it is already mobilized in everyday situations" but a process of professionalization [14]. If the author takes the concept of help as an example, it seems more relevant for our purpose to evoke the concept of observation, at the heart of the practice of our profession. Observing the other as an ergonomist is not just looking at the progress of an action or an object as would be the case on a daily basis, but it is mobilizing know-how and methods to understand the activity. It means doing it in a way that is always singular according to the particularities of the situation and the operators with whom they are conducted. Observation will thus require adjustments in its practice, adjustments made according to the singularity of the situation, based on a set of clues taken all along from the work environment, the worker or one-self... It is this work of putting together a set of elements to create an operative and professional model of observation which will be necessary for the beginner ergonomist. 
We therefore hypothesize a double process of pragmatization and professionalization of the concepts which takes place in the early stages of the professional practice of the ergonomist. This process is difficult, it is not without certain clashes and questions, which require space for discussion. However, while the existence of problems specific to young practitioners, or at least more marked ones, explains the need for exchange, it does not necessarily explain the difficulty of instructing them in existing spaces and with the community as a whole.

\subsection{The lack of reflective space for practice}

The ergonomics community offers many opportunities for exchange. They take extremely diverse forms, ranging from the most formal and wide-ranging events represented by the various congresses to the simplest meetings, such as the convivial moments offered locally by the various ergonomics associations. However, each of these spaces, although they participate in the life and construction of our community, are the result of specific objectives that do not really fall within the scope of the debate on professional practice. The closest events, the congresses, seem to us rather to pursue a logic of construction of a professional identity. They enable the development of the professional "gender" [7], which can be succinctly defined as collective practice, the rules of the profession, but they do not aim to debate individual "styles" [7] understood as an individual declination of the "gender", which differs for each ergonomist.

Moreover, talking about ones practice is not easy. It is necessary to talk about oneself and sometimes about one's difficulties and failures. It may be a matter of assuming certain wanderings, other times of sharing a concession that is difficult to make to one's professional ethics to allow the intervention to be carried out. This requires a "protective framework" [1] to be able to do so. If we take the example of the Congress, the public character can thus limit this possibility of free speech. In any case, this difficulty in speaking out is even more marked for the young practitioner, whose confidence in they own practice still benefits only marginally from the benefits of experience.

But it is perhaps another object which complicates the speaking out of young practitioners and which relates to social relationships. While studies on the impact of speaking in groups focus mainly on other social relationships $[5 ; 6]$, we hypothesize that certain factors such as experience, prestige and, more generally, status within a community can have an impact on speaking. Far be it from us to attempt to erase other, much more documented social relationships, but rather to underline the idea that, despite all the goodwill we can show, we remain part of a multitude of social relationships that no amount of discussion engineering can perfectly erase. In practice, it may thus be difficult for the young practitioner to speak to more experienced people. It will be even more complex for they to move from a listening and learning posture to enter an egalitarian position and debate their practices.

Here again, this is only an attempt on our part to explain the Committee's challenge by the need felt by some young practitioners to gather and talk about their difficulties, a need that is now reflected in the objectives that the Committee has set itself: the creation of spaces for exchanges on practice, the development of the professional network and encouraging the setting in motion of these exchanges within the profession.

\section{The heart of our engineering: the reflexive professional storytelling}

To meet this need of young practitioners, the Committee organizes exchange days on practice. However, for a discussion on practice to take place, it is not enough to simply decree it. A real 
engineering must be thought out for the exchange to be operational [11;20]. The core of the one we have chosen is based on the mobilization of professional storytelling from the young practitioners themselves and is inspired by the work of Beaujouan [3]. However, unlike this work, this is not a "professional storytelling with didactic aims" [3], but a reflexive professional storytelling.

An example of a professional storytelling will be provided in the second paper of this symposium ${ }^{1}$, so we will not detail the characteristics of the storytelling itself here. However, it seems important to situate it in relation to certain uses of storytelling that have inspired it or are relatively close to it.

The fundamental difference between professional storytelling with a didactic aim [3] and reflexive professional storytelling lies in its purpose. In the original works, the professional storytelling is mobilized to enable the transmission of teaching within the framework of the training of ergonomists. This difference is not anecdotal since it will induce adjustments in the construction of the professional storytelling, the objective not being centered on the message and its intelligibility, but on its capacity to become a tool for convening and mobilizing the individual experience of each participant. It must therefore have sufficient elements and depth to allow for debate and not be a teaching tool, but rather a questioning one.

Storytelling is also a classic tool within a community of practice [13]. It enables the transmission of experience within the community and the collective construction of a common history. Here too, although the creation of links is the object of the stories we mobilize, it differs from this conventional use by their inclusion in the temporality of the event that the day represents. They are not in-tended to circulate outside these spaces. However, "the shared practice within a CoP [Community of Practice] acts as a cement between the members or as a source of coherence that collectively allows them to search for meaning in the way they consider and apply their profession" [9] and it is this linking function that is sought in the mobilization of the storytelling during the JPR days of exchange on practices.

Thus, it is more of a "boundary object" [18;19] within a community of practice, "these objects are often the provisional result of the process of reification of practice by the members" [9]. This process of reification, the ability to make practice tangible and debatable, is the central purpose of the reflexive professional storytelling. Qualifying the reflexive professional storytelling as a bounda-ry object highlights all its other characteristics, such as the interpretative flexibility that will open the debate between practitioners. It is thus both concrete and abstract, specific, and general, conventional and customizable [19]. Concrete as it deals with a real experience. Abstract as this experience is reconstructed, narrated. Specific, because each intervention is a specific case, with elements related to the practice of ergonomics of the activity. General, because of its capacity to allow the expression of the different forms of activity ergonomics such as in-house practice, consultancy, in an occupational health service or as a researcher, but also all the different professional types of participants. Conventional as it is always an intervention, with certain specific codes. Customizable, because at any time it can be completed and enriched by the participant. It finally allows the production of knowledge by the participants. This knowledge is first of all of a conceptual and collective nature. It is however, also and above all an individual and reflexive nature for each practitioner.

\footnotetext{
${ }^{1}$ Eisenbeis A., Bachellerie C.,(2021), Contributions and construction of the professional story-telling within the framework of a Junior Practices in Reflection day: the example of a design project in a municipality, IEA $21^{\text {st }}$ Triennial Congress
} 


\section{Conclusion: Storytelling, a tool with multiple variations}

Since the creation of the Commission, the foundations of this engineering have been developed in several formats. The first takes the form of a full day, around a specific theme. This will be more detailed in symposium's third article ${ }^{2}$. To date, 13 events have been held on this model, which remains the core of the commission's activities.

On the SELF 54th congress in 2019, a new format was tested in a shorter time frame [8]. It was open to all practitioners regardless of their experience. Taking the form of 3 workshops, they showed the interest of this type of approach for the whole community. However, they also confirmed the need to maintain time for exchange between novice practitioners to allow free expression. In particular by the observation of the expert posture from which it was difficult to emerge. Therefore, to this day, we favor the development of the interface with the community and the organization of mixed events in parallel and in addition to the events aimed for novice practitioners.

In order to create a link during the confinement period from March to May 2020 in France, another format has been tested. Throughout this period, weekly and distance meetings were offered to young practitioners. They enabled them to discuss topics related to the impact of the health crisis on the current and future practice of ergonomists. These sessions were rich in exchanges and gave rise to a summary article. On the form, they were an opportunity to start a reflection on a new distanced engineering which construction continues today. Without being able to replace the face-to-face, it is a necessary adaptation in response to the crisis we are going through.

This engineering has also given rise to international developments, which will be the subject of the fourth paper of this symposium ${ }^{3}$. Participation in this congress is also part of this dynamic of dialogue with the international community.

As a result of these diverse experiences, the SELF'S JPR Committee has evolved both in the actions it undertakes within the community and in the forms of discussion on its practice. The experience acquired over the years also shows the effectiveness of the methodological protocol that has been developed and the conviction of the interest of these discussion forums for novice ergonomists.

\section{$\underline{\text { References }}$}

1. Albert, V. (2007). 5. Vers une démarche d'intervision. Supervisions écosystémiques en travail social, Relations (p. 81-94). Toulouse : ERES.

2. Altet, M. (2002). Une démarche de recherche sur la pratique enseignante : L'analyse plurielle. Revue française de pédagogie, 138(1), 85-93.

3. Beaujouan, J. (2011, novembre 21). Contributions des récits professionnels à l'apprentissage d'un métier : Le cas d'une formation d'ergonomes. (Thesis). Bordeaux 2.

4. Beaujouan, J., \& Daniellou, F. (2012). Les récits professionnels dans une formation d'ergonomes. Le travail humain, 75(4), 353-376. Paris : Presses Universitaires de France.

\footnotetext{
${ }^{2}$ Bachellerie C. et al. (2021), Building spaces for discussion: getting the diversity of practices speak, in: IEA $21^{\text {st }}$ Triennial Congress

${ }^{3}$ Mestanza M., et al. (2021), The exchange on practice: an issue for the development of novice ergonomists in Peru in a context where practices of ergonomic are heterogeneous, in: IEA $21^{\text {st }}$ Triennial Congress
} 
5. Blanchard-Laville, C. (Éd.). (1997). Variations sur une leçon de mathématiques: Analyse d'une séquence, "l'écriture des grands nombres. Paris : L'Harmattan.

6. Chevet, M. (2006). L'impact du genre dans la relation entre enseignant-e-s et apprenant-e-s. Ela. Etudes de linguistique appliquee, no 142(2), 163-174. Klincksieck.

7. Clot, Y. (1999). La fonction psychologique du travail. Paris : Presses universitaires de France.

8. Cromer, D., Cléret, M., Marié, J., Toulisse, C., Chambel, A., \& Bachellerie, C. (2019). Quand les expériences se rencontrent: Une opportunité de développement des pratiques de chacun. 55ème Congrès de la SELF, Comment contribuer à un autre monde ? Tours, France.

9. Daele, A. (2009). Les communautés de pratique. Encyclopédie de la formation, 721-730. PUF Paris.

10. Daniellou, F. (2006). Entre expérimentation réglée et expérience vécue. Les dimensions subjectives de l'activité de l'ergonome en intervention. Activités, 03(3-1). ARPACT - Association Recherches et Pratiques sur les Activités.

11. Detchessahar, M. (2001). Quand discuter, c'est produire... Pour une théorie de l'espace de discussion en situation de gestion. Revue française de gestion, (132), 32-43.

12. Falzon, P. (2004). 1. Nature, objectifs et connaissances de l'ergonomie. Éléments d'une analyse cognitive de la pratique. Ergonomie, Hors collection (p. 15-35). Paris cedex 14 : Presses Universitaires de France.

13. Lave, J., \& Wenger, E. (1991). Situated learning: Legitimate peripheral participation. Situated learning: Legitimate peripheral participation (p. 138). New York, NY, US: Cambridge University Press.

14. Mayen, P. (2007). Quelques repères pour analyser les situations dans lesquelles le travail consiste à agir pour et avec un autre. Recherches en éducation, 4, 51-64.

15. Pastré, P. (1999). La conceptualisation dans l'action : Bilan et nouvelles perspectives. Éducation permanente, $\left(n^{\circ} 139\right), 13-35$.

16. Samurçay, R., \& Pastré, P. (1995). La conceptualisation des situations de travail dans la formation des compétences. Education permanente, (123), 13-32. Université de Paris-Dauphine.

17. Schön, D. A. (1983). The reflective practitioner: How professionals think in action. New York: Ashgate.

18. Star, S. L. (2010). Ceci n'est pas un objet-frontière ! Revue d'anthropologie des connaissances, Vol 4, $n^{\circ} 1(1), 18-35$.

19. Star, S. L., \& Griesemer, J. R. (1989). Institutional Ecology, 'Translations' and Boundary Objects: Amateurs and Professionals in Berkeley's Museum of Vertebrate Zoology, 1907-39. Social Studies of Science, 19(3), 387-420.

20. Van Belleghem, L., \& Forcioli Conti, E. (2015). Une ingénierie de la discussion ? Chiche! Actes du 50ème Congrès de la SELF. Présenté à Articulation performance et santé dans l'évolution des systèmes de production, Paris.

21. Viau-Guay, A. (2009). Analyse de l'activité déployée par un ergonome lors de difficultés professionnelles : Contribution à la formation initiale. 
22. Vidal-Gomel, C., \& Rogalski, J. (2007). La conceptualisation et la place des concepts pragmatiques dans l'activité professionnelle et le développement des compétences. Activités, 04(4-1). ARPACT - Association Recherches et Pratiques sur les Activités.

23. Wenger, E. (1998). Communities of practice: Learning, meaning, and identity. Communities of practice: Learning, meaning, and identity (p. xv, 318). New York, NY, US: Cambridge University Press. 